\title{
FACTORS INFLUENCING LACTATION
}

\section{PART I. MATERNAL}

\author{
BY \\ R. A. MILLER \\ From the Roval Hospital for Sick Children, Edinburgh and the Department of Child Life and Health,
University of Edinburgh
}

(RECEIVED FOR PUBLICATION OCTOBER 8, 1951)

\begin{abstract}
Numerous factors have been reported to influence lactation. The role they play is hard to assess, and is generally based on either clinical impressions or inclusive evidence. Views on the importance of certain factors are conflicting, and from time to time a different factor is regarded as the most significant. Thus in the past different remedies have been advocated for difficulties in breast feeding though without any great success, beyond the stimulation of the medical and nursing profession to take more interest and care in helping women over their breast feeding difficulties. It would therefore seem desirable to assess more accurately the significance of various maternal factors which are reputed to impair lactation. The maternal factors which have been studied are age, parity, height, weight and health in pregnancy.
\end{abstract}

\section{Material and Methods}

Separate investigations were made of the effect of age, parity and pre-eclamptic toxaemia upon the duration of breast feeding. The women selected were those delivered in the Simpson Memorial Maternity Pavilion, Edinburgh, during 1948 and 1949. Two further groups of women, selected for studies on the possible relationship of height and weight to successful lactation, were chosen from women who were treated in the same hospital, but between January, 1947, and June, 1950. In all the investigations except that upon pre-eclamptic toxaemia every woman had given birth to a mature live infant. Women with twins were not investigated. Women with premature infants as well as mature infants were studied in the investigation on pre-eclamptic mothers. In each group every mother who fulfilled the conditions and fell within the limits of the investigation was included. The control groups of women who were compared with the groups under investigation were selected from women treated in the Simpson Memorial Maternity Pavilion during the periods of the investigations: these women, however, were selected at random, a similar number being chosen from every 1,000 consecutive admissions to hospital. The control groups were made comparable with the special groups by selecting mothers with either mature or mature and premature infants. Moreover, women with twins were excluded.

In the investigations relating to age, parity and pre-eclamptic toxaemia, two points were established; the first was the incidence of breast feeding, partial breast feeding and artificial feeding among the selected group of women at the time they left hospital. This was almost invariably the tenth day of the puerperium. If, as occasionally happened the mother stayed in hospital for more than two weeks after parturition, the method of infant feeding in use on the fourteenth day of the puerperium was recorded. The second was the effect of the factor under investigation upon the duration of breast feeding. This was established by following up for six months every woman with that factor who was entirely breast feeding her infant when she left hospital. The number and percentage of these women who were breast feeding for one, two, three, four, five and six months were calculated and recorded. Women who belonged to the group but who were giving their infants complementary feeds when they left hospital were similarly investigated.

In the investigation concerning women's height and weight both the mother and the infant were weighed at the hospital welfare clinic in the third or fourth week after the birth of the infant. They 
were re-weighed each time the mother brought the infant for re-examination at the clinic, which was usually once a week. A record of the mother's weights was kept as well as her age and height. A note was also made of the mother's weight before she was pregnant. The infant's weights and method of feeding were recorded. From the data, both the mother's height and weight was correlated with the duration of breast feeding. The mother's weight was also correlated with the infant's weight progress provided the infant was breast fed.

\section{Age}

Studies on the influence of age upon lactation have shown that older women tend to have a lower milk yield during the first week of lactation (König, 1939; Ström, 1947; Waller, 1950) and more often stop breast feeding prematurely than do younger women (Woodbury, 1925; Stewart and Pratt, 1941). Robinson (1942), Norval (1947) and Herlitz (1946) confirmed this and considered that the reduction in the incidence of breast feeding occurred after women reached the age of 30 . On the other hand Friedländer (1917), Bendix (1928) and Broman, Dahlberg and Lichtenstein (1942), considered that elderly women breast fed their infants longer than younger women. According to Herlitz (1946) and Douglas (1950), the different incidence of breast feeding in the two age groups was not statistically significant. Herlitz (1946) believed that the possible difficulty in breast feeding amongst older women was due to a relatively lower milk yield, but that this difficulty was minimized by the fact that a larger proportion of elderly women are multipara with a greater knowledge of breast feeding and a greater desire to breast feed their infants than younger women.

In this investigation the influence of age upon lactation has been ascertained by determining the percentage of both young and old mothers breast feeding their infants. The investigation involved two groups, primiparae and multiparae. In the first a group of 1,120 primiparae under 35 (young) was compared with a group of 135 primiparae over 35 (old). The percentage of women fully breast feeding, partially breast feeding and artificially feeding in each of the two groups of women in the second week of the puerperium was determined and the results recorded in Table 1. The results show that the proportion of women who fail to breast feed their infants satisfactorily in the second week of lactation is at least $32 \%$ greater in the group of elderly primipara.

The same method of investigation was adopted to compare the incidence of lactation in a group of 655 multiparae under 40 (young) with that of a group of 114 multiparae over 40 (old). These results were also recorded in Table 1. Again the

TABLE 1

INCIDENCE OF Different Types OF INFANT FeEDING IN Young and OLd Primipara and Multipara IN THE Second Week of the Puerperium

\begin{tabular}{|c|c|c|c|c|}
\hline \multirow[b]{2}{*}{ Group } & \multirow[b]{2}{*}{$\begin{array}{c}\text { No. of } \\
\text { Cases }\end{array}$} & \multicolumn{3}{|c|}{ Percentage } \\
\hline & & $\begin{array}{c}\text { Com- } \\
\text { plete } \\
\text { Breast } \\
\text { Feeding }\end{array}$ & $\begin{array}{l}\text { Partial } \\
\text { Breast } \\
\text { Feeding }\end{array}$ & $\begin{array}{l}\text { Arti- } \\
\text { ficial } \\
\text { Feeding }\end{array}$ \\
\hline $\begin{array}{l}\text { Young primipara } \\
\text { Old primipara } \\
\text { Young multipara } \\
\text { Old multipara }\end{array}$ & $\begin{array}{r}1,120 \\
135 \\
655 \\
114\end{array}$ & $\begin{array}{l}81 \\
49 \\
82 \\
46\end{array}$ & $\begin{array}{r}9 \\
27 \\
9 \\
30\end{array}$ & $\begin{array}{r}10 \\
24 \\
9 \\
24\end{array}$ \\
\hline
\end{tabular}

figures show that the greater percentage of elderly multiparae are unable to breast feed their infants adequately in the second week of the puerperium. Thus, when comparing the incidence of breast feeding among elderly mothers with that found among young mothers, it is apparent that a larger proportion of elderly mothers irrespective of whether they are multiparae or primiparae require to give complementary or completely artificial feeds to their infants.

An investigation was also made into the duration of lactation among young and old mothers. Again primiparae were compared with primiparae and multiparae with multiparae. The ages dividing the young from the old were the same as in the first part of the investigation. For this purpose 145 young primiparae and 33 old primiparae, all of whom were breast feeding their infants completely and satisfactorily when they left hospital, were followed up. The number in each group that breast fed for one, two, three, four, five and six months was determined. From the results the percentage of women in each group who lactated for one, two, three, four, five and six months was calculated and recorded in Table 2. From this table it is apparent that the percentage of women continuing to breast feed from month to month was similar in the two groups.

The duration of lactation of 107 young multiparae and 550 old multiparae who were completely breast feeding their infants in the second week of the puerperium was investigated in a similar manner. The results have been recorded in Table 2 . They show that the percentage of elderly multiparae who breast feed for one, two, three, four, five and six months respectively is similar to the percentage 
TABLE 2

Duration of Breast Feeding of 'Young' and ' Old' Primipara and Multipara

\begin{tabular}{|c|c|c|c|c|c|c|c|c|c|c|}
\hline \multirow[b]{2}{*}{ Group } & \multirow[b]{2}{*}{ Age } & \multirow{2}{*}{$\begin{array}{l}\text { Lactation } \\
\text { in } \\
\text { Hospital }\end{array}$} & \multirow{2}{*}{$\begin{array}{l}\text { No. } \\
\text { of } \\
\text { Cases }\end{array}$} & \multicolumn{7}{|c|}{ Percentage Lactating Each Month } \\
\hline & & & & $\frac{1}{2}$ & 1 & 2 & 3 & 4 & 5 & 6 \\
\hline $\begin{array}{l}\text { Primipara } \\
\text { Multipara } \\
\text { Primipara } \\
\text { Multipara }\end{array}$ & $\begin{array}{l}\text { Young } \\
\text { Old } \\
\text { Young } \\
\text { Old } \\
\text { Young } \\
\text { Old } \\
\text { Young } \\
\text { Old }\end{array}$ & $\begin{array}{l}\text { Adequate } \\
\text { Adequate } \\
\text { Adequate } \\
\text { Adequate } \\
\text { Inadequate } \\
\text { Inadequate } \\
\text { Inadequate } \\
\text { Inadequate }\end{array}$ & $\begin{array}{r}145 \\
154 \\
107 \\
114 \\
130 \\
19 \\
51 \\
18\end{array}$ & $\begin{array}{l}100 \\
100 \\
100 \\
100 \\
100 \\
100 \\
100 \\
100\end{array}$ & $\begin{array}{l}88 \\
98 \\
93 \\
93 \\
49 \\
37 \\
34 \\
22\end{array}$ & $\begin{array}{r}68 \\
69 \\
78 \\
79 \\
23 \\
16 \\
17 \\
6\end{array}$ & $\begin{array}{r}58 \\
60 \\
71 \\
71 \\
17 \\
16 \\
14 \\
6\end{array}$ & $\begin{array}{r}54 \\
54 \\
58 \\
59 \\
12 \\
10 \\
9 \\
0\end{array}$ & $\begin{array}{r}50 \\
50 \\
52 \\
52 \\
11 \\
10 \\
7 \\
0\end{array}$ & $\begin{array}{r}47 \\
47 \\
50 \\
52 \\
11 \\
5 \\
6 \\
0\end{array}$ \\
\hline
\end{tabular}

of young multiparae lactating for those periods. It is therefore apparent that breast feeding at this stage of lactation is as satisfactory in elderly mothers as in young mothers, be they primiparae or multiparae.

A study has been made of the duration of breast feeding in young and old women who require to give their infants complementary feeds in the second week of the puerperium. The investigation was conducted along the same lines involving multiparae and primiparae who were completely breast feeding their infants when discharged from hospital. The percentage of both 130 young and 19 old primiparae and of a group of 51 young and a group of 18 old multiparae breast feeding for one, two, three, four, five and six months was determined and recorded in Table 2. The results obtained for young mothers did not differ appreciably from those obtained for old mothers. Thus evidence has been given to show that age does not influence a woman's ability to breast feed her infant after the second week of the puerperium.

The deductions drawn from the investigation into the possible relationship between age and lactation are: first, a higher proportion of older women, both multiparae and primiparae, have to give their infants complementary feeds during the second week of lactation and such mothers usually wean their infants soon after leaving hospital. Those who leave hospital fully breast feeding their infants continue to breast feed for as long as the control series of mothers. Secondly, a higher proportion of elderly women, both primiparae and multiparae, have to give artificial feeds to their infants before they leave hospital, which is usually on the tenth day of the puerperium. Thirdly, it is known that approximately $3 \%$ of all women leaving the Simpson Memorial Maternity Pavilion while these investigations were in progress were primiparae over 35 and $4 \%$ were multiparae over 40. It is therefore apparent that in only a very small proportion of the many women who wean their infants prematurely can weaning be attributed to the mother's age.

\section{Parity}

Reports on the influence of parity upon successful breast feeding vary. Peckham (1934), and Herlitz (1946) considered multiparae to be more successful in breast feeding than primiparae. This was probably due to multiparae being more experienced and physiologically better adapted to nurse (Herlitz, 1946), and to lactation in primiparae being more readily affected by ill health (König, 1939; Ström, 1947). It has been stated that close pregnancies may give rise to early weaning (Woodbury, 1925; Royal College of Obstetrics and Gynaecologists, 1948). More convincing evidence however has been given by Norval (1947), by Dykes (1949) and by Douglas (1950) to show that parity does not influence the duration of breast feeding.

To confirm or refute the general impression that parity did not influence a woman's ability to breast feed her infant the incidence and duration of lactation in multiparae and primiparae have been compared. The data used in the investigation into age and lactation have been re-examined. The incidence of breast feeding, partial breast feeding and artificial feeding amongst 1,255 primiparae was compared with that of 769 multiparae at the end of the second week of the puerperium. These women were of all ages and were selected at random from cases which were treated in hospital in 1948 and 1949. From Table 1 it is apparent that the incidence of breast feeding or partial breast feeding for primiparae does not differ appreciably from that for multiparae in the second week of lactation.

The duration of breast feeding of primiparae and of multiparae was also investigated. A group of 299 primiparae and one of 221 multiparae, comprising women who were entirely breast feeding when discharged from hospital, were followed up 
for six months. The percentage of women in each group who breast fed their infants for one, two, three, four, five and six months was recorded in Table 2. The results indicated that the two groups of mothers were equally successful in breast feeding their infants for six months.

A similar investigation was made upon 149 primiparae and 69 multiparae who were giving their infants complementary feeds when they left hospital. The results given in Table 2 show that approximately the same percentage of women in the two groups breast feed their infants for six months.

\section{Weight and Height}

After childbirth many women are concerned about their weight because they consider they are too heavy or else because they are too light. Despite these complaints few studies of women's weight during lactation have been recorded. From those which are available it appears that the majority of women initially lose weight, on the average $2.30 \mathrm{~kg}$. in the first 10 days and $0.68 \mathrm{~kg}$. in the next 35 days (Stander and Pastore, 1940). They then gain weight until a month before or after their milk production has reached its maximum after which they again lose weight (Ylinen, 1937). Some women, however, steadily gain weight or lose weight (Ylinen, 1937). The older conception differed from this in that most women gained weight when they breast fed their infants (Schlossmann, 1905; Finkelstein, 1921; Laurentius, 1911; Peckham, 1934).

Both women's height and weight have been correlated with their milk yield or their ability to breast feed their infants. Wardlaw and Dart (1934) noted that undersized women tend to have lighter infants and smaller milk yields than taller women. Others have investigated the possible relationships of women's milk yield to body weight and failed to detect such a relationship (Macy, Hunscher, Donelson and Nims, 1930; Ylinen, 1937). Nevertheless, Ylinen (1937) considered that if a larger series of observations were made it might be possible to show that women who lost weight had on the average a better milk yield than mothers whose weight fluctuated or steadily rose. Observations made on women's nutrition and ability to breast feed their infants adequately have been made in countries where various degrees of under-feeding or starvation have existed. The results of these observations showed that undernourished women may have difficulty in breast feeding, some being able to breast feed their infants satisfactorily for a limited period while others never lactate adequately (Kütting, 1921 ; Kerpel-Fronius, 1947; Antonov,
1947; Dean, 1949). The different response to undernourishment was probably dependent on the type and degree of the dietetic deficiency, and evidence suggests that only grossly abnormal diets taken for a considerable period of time affect lactation adversely.

One investigation of the possible relationship of women's height, and two of the possible relationship of women's weight to their ability to lactate adequately have been made. That dealing with height was made to determine whether women under $5 \mathrm{ft}$. were as successful in breast feeding as taller women. To this end, a group of 123 women under $5 \mathrm{ft}$. and one of 1,487 women over $5 \mathrm{ft}$. were examined, and the number in each group who completely breast fed, partially breast fed and artificially fed their infants in the second week of lactation was determined. From these results the percentage of each group breast feeding, partially breast feeding and artificially feeding their infants was calculated and recorded in Table 3 . The

TABLE 3

INCIDENCe of Different Types of Feeding in Women UNDER AND OVER 5 FT. IN THE SeCOND WeEk OF THE PuerperiuM

\begin{tabular}{|c|c|c|c|c|c|}
\hline \multirow[b]{2}{*}{ Group } & & \multirow[b]{2}{*}{$\begin{array}{l}\text { No. of } \\
\text { Cases }\end{array}$} & \multicolumn{3}{|c|}{ Percentage } \\
\hline & & & $\begin{array}{c}\text { Com- } \\
\text { plete } \\
\text { Breast } \\
\text { Feeding }\end{array}$ & $\begin{array}{l}\text { Partial } \\
\text { Breast } \\
\text { Feeding }\end{array}$ & $\begin{array}{l}\text { Arti- } \\
\text { ficial } \\
\text { Feeding }\end{array}$ \\
\hline $\begin{array}{l}\text { Over } 5 \mathrm{ft} \text {. } \\
\text { Under } 5 \mathrm{ft} \text {. }\end{array}$ & $\cdots$ & $\begin{array}{r}1,487 \\
123\end{array}$ & $\begin{array}{l}79 \cdot 5 \\
81 \cdot 3\end{array}$ & $\begin{array}{c}10 \cdot 2 \\
8 \cdot 95\end{array}$ & $\begin{array}{c}10 \cdot 3 \\
9 \cdot 75\end{array}$ \\
\hline
\end{tabular}

percentage obtained for the two groups was compared, and showed that women under $5 \mathrm{ft}$. were as successful in breast feeding in the second week of the puerperium as women over $5 \mathrm{ft}$.

The duration of breast feeding was studied in a group of 75 women who were under $5 \mathrm{ft}$. and a group of 280 women over $5 \mathrm{ft}$. All these women were entirely breast feeding their infants in the second week of the puerperium, and were followed up for six months. The number and percentage of women in each group who breast fed for one, two, three, four, five, and six months was ascertained. The percentage of each group who were breast feeding at each monthly stage is shown in Fig. 1, from which it is apparent that $53 \%$ of the women over $5 \mathrm{ft}$. breast feed their infants for six months while only $33 \%$ of women under $5 \mathrm{ft}$. breast feed for the same length of time. The difference is statistically significant. Thus, in this 
investigation women under $5 \mathrm{ft}$. were not as successful in breast feeding their infants as the taller women. The degree of impairment in lactation noted in the small women, however, does not contribute to any great extent to the large number of prematurely weaned infants, because only $10 \%$ (approximately) of all women admitted to maternity wards are under $5 \mathrm{ft}$.

The possible relationship between the mother's weight in the third and fourth week of the puerperium and the duration of her lactation has been investigated. Two groups of women were used; one comprised 176 women who were below the average weight for their height and age, and the average weight for their height and age when they were weighed in the third or fourth week of the puerperium. All their weights, however, were within the range of normal for both non-pregnant or non-lactating women and the standards were those quoted by Werner (1942). Each woman was weighed on the same machine and all were followed up for six months. They all were completely breast feeding their infants when they left hospital. The number and percentage of each group of women who breast fed for one, two, three, four, five and six months was recorded in Table 4. The results suggest that the heavier group of women breast feed their infants on the average longer than the lighter group of women. The difference between the two groups is not statistically significant.

It was not possible to follow up many women who were either below or above the normal weight for their age and height. Nevertheless the results obtained for six women who were below normal weight (underweight) and for 42 women who were above normal weight (overweight) in the third and fourth week of the puerperium deserve comment. The overweight women were investigated in the same way as were those described in the previous paragraph and the percentage breast feeding for six months (55\%) recorded (Table 4). All the women were entirely breast feeding their infants when they left hospital in the second week of the puerperium. The results of this investigation other comprised 207 women who were over the

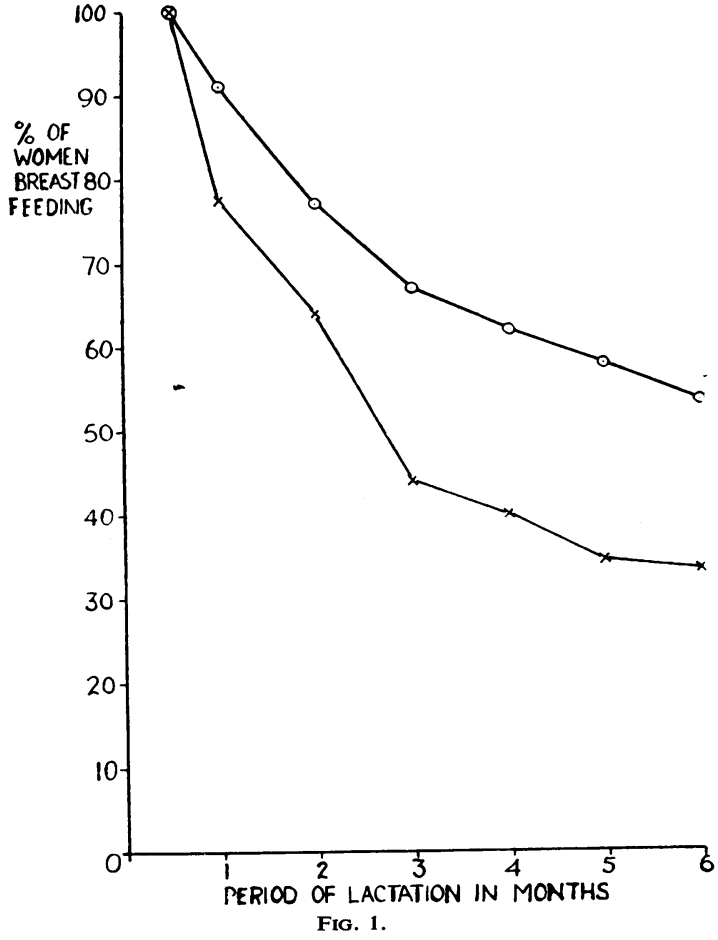

FIG. 1. - The duration of breast feeding among women who were both under $(x)$ and over $(\odot) 5 \mathrm{ft}$. tall.

indicated that the women who were overweight on the average breast fed for approximately the same period as women of average weight. The follow-up of the six women who were underweight showed that two of them breast fed for six months and in these cases the health of both the mother and infant was satisfactory. Thus some underweight women can breast feed their infants as satisfactorily as heavier women.

The second investigation into women's weights was made by comparing the weight progress of breast fed infants belonging to mothers whose weight increased during the first six months of

TABLE 4

Weight in the Third and Fourth Week of the Puerperium Correlated with the Duration of Lactation

\begin{tabular}{|c|c|c|c|c|c|c|c|c|c|}
\hline \multirow[b]{2}{*}{ Group } & & \multirow{2}{*}{$\begin{array}{l}\text { No. of } \\
\text { Cases }\end{array}$} & \multicolumn{7}{|c|}{ Percentage Lactating Each Month } \\
\hline & & & $\frac{1}{2}$ & 1 & 2 & 3 & 4 & 5 & 6 \\
\hline $\begin{array}{l}\text { Overweight } \\
\text { Heavy } \\
\text { Light }\end{array}$ & $\begin{array}{l}\ldots \\
\cdots \\
\ldots\end{array}$ & $\begin{array}{r}42 \\
207 \\
176\end{array}$ & $\begin{array}{l}100 \\
100 \\
100\end{array}$ & $\begin{array}{l}86 \\
91 \\
84\end{array}$ & $\begin{array}{l}79 \\
80 \\
74\end{array}$ & $\begin{array}{l}71 \\
74 \\
61\end{array}$ & $\begin{array}{l}64 \\
65 \\
52\end{array}$ & $\begin{array}{l}60 \\
63 \\
51\end{array}$ & $\begin{array}{l}55 \\
59 \\
50\end{array}$ \\
\hline
\end{tabular}


TABLE 5

Correlation of Infant's Weight Gain with Mother's Weight Gain or Loss during First 6 Months of LACTATION

\begin{tabular}{|c|c|c|c|c|c|c|c|c|c|}
\hline \multirow{2}{*}{$\begin{array}{l}\text { Mother's } \\
\text { Weight }\end{array}$} & & \multirow{2}{*}{$\begin{array}{l}\text { No. of } \\
\text { Cases }\end{array}$} & \multicolumn{7}{|c|}{ Average Weight of Infant (lb. oz.) at } \\
\hline & & & Birth & 4 wks. & 8 wks. & 12 wks. & 16 wks. & 20 wks. & 26 wks. \\
\hline $\begin{array}{l}\text { Increased } \ldots \\
\text { Decreased }\end{array}$ & $\begin{array}{l}\cdots \\
\cdots\end{array}$ & $\begin{array}{r}89 \\
212\end{array}$ & $\begin{array}{l}7 \cdot 9 \\
7 \cdot 6\end{array}$ & $\begin{array}{l}8 \cdot 12 \\
8 \cdot 11\end{array}$ & $\begin{array}{l}10 \cdot 6 \\
10 \cdot 8\end{array}$ & $\begin{array}{l}12 \cdot 1 \\
12 \cdot 3\end{array}$ & $\begin{array}{l}13 \cdot 9 \\
13 \cdot 11\end{array}$ & $\begin{array}{l}14 \cdot 13 \\
14 \cdot 15\end{array}$ & $\begin{array}{l}16 \cdot 6 \\
16 \cdot 7\end{array}$ \\
\hline
\end{tabular}

lactation with that of breast fed infants belonging to mothers whose weight decreased during the first six months of lactation. The women selected for the investigation were weighed in the third or fourth week of lactation and again at approximately the sixth month of lactation. The two values for each woman were compared; 212 lost from 1 to $23 \mathrm{lb}$., or an average of $9 \frac{1}{2} \mathrm{lb}$., during this time and 89 gained from 1 to $64 \mathrm{lb}$., or an average of $7 \frac{1}{3} \mathrm{lb}$. Many of these women were weighed frequently during the six months that they were under investigation and these cases almost always showed a constant rise or else a constant fall in weight. It was therefore apparent that fluctuation in both directions was unusual. The weight progress of the infants belonging to these mothers was recorded every week or every other week during the period of investigation. The infants were entirely breast fed until they were about 5 months old after which mixed feeding was gradually introduced in many cases. The average weight for each group of infants during the first six months of life was calculated from the results and recorded in Table 5. From inspection of Table 5 it is apparent that the difference between the two groups is not great. This might well occur by chance because the weight gain of infants varies greatly from case to case. Therefore, the variation in the mother's weight during lactation does not bear any relationship to her infant's weight progress as judged by the present series of observations on apparently healthy women. The investigation also revealed that $70 \%$ of mothers lose weight in the first six months of lactation while almost $30 \%$ gain weight throughout that period. Moreover, out of a series of 210 women in the first six months of lactation, $36 \%$ had returned to their pre-pregnant weight. The remaining women $(64 \%)$ were still above their normal weight after lactating for six months. It appears, therefore, that both an increase or decrease in weight during lactation is a physiological process and that the change can be very marked without affecting either the mother's or infant's health and progress adversely.

\section{Health in Pregnancy}

Pregnant women are liable to the same diseases as the general public. Some diseases, such as acromegaly (Cameron, 1947) and the ArnoldChiari syndrome, are associated with galactorrhoea (Ashkar, 1950), while others causing a systemic disturbance may impair a woman's chances of breast feeding her infant. It is stated that women with pyelitis (König, 1939; Robinson, 1942), nephritis and eclampsia during pregnancy (Peckham, 1933) are less likely to breast feed their infants than women who have been healthy during pregnancy. Whether pre-eclamptic toxaemia has a similar effect upon lactation is doubtful; Peckham (1933) and Brash (1948) state that the condition has on the average a deleterious effect upon lactation, but Robinson (1942) failed to confirm their conclusion. Disorders giving rise to no apparent systemic disturbance, as in the majority of cases of anaemia, albuminuria (Ström, 1947), lactosuria (Joslin, 1940) and enlargement of the thyroid gland without thyrotoxicosis (Robinson, 1942) do not affect lactation adversely. Owing to the difference of opinion on the effects of pre-eclamptic toxaemia upon lactation this problem has been investigated. No attempt, however, has been made to study the effects of other diseases that may occur in pregnancy because of the difficulty in obtaining a large enough series of women with a specific illness for such an investigation.

To this end a series of 292 women with preeclamptic toxaemia was investigated; 244 of these had mature infants and $\mathbf{4 8}$ had premature infants. They have been compared with two series of women who had not suffered from pre-eclamptic toxaemia; one comprised 3,058 women with either mature or premature infants and the other-1,899 women all of whom had mature infants. No mother in either series had twins. Every woman of both pre-eclamptic and control groups was examined during the second week of the puerperium and her method of feeding her infant noted under one of three headings, breast feeding, partial breast feeding and artificial feeding. The percentages of 
pre-eclamptic women with mature infants in each group were then compared with the percentage of the control women with mature infants in each group. A similar comparison was made between preeclamptic women with mature and immature infants and the group of control women with mature and immature infants. The incidence of complete breast feeding, partial breast feeding and artificial feeding for each of these groups of women has been shown in Table 6. The figures indicate that in the groups with mature infants a greater percentage of pre-eclamptic women gave their infants complementary or artificial feeds than in the control series, there being $10 \%$ fewer preeclamptic women fully breast feeding their infants in the second week. When women with premature infants were included in the two groups the differences became more marked. This is partly due to the proportion of pre-eclamptic women with premature infants being greater than that of the control series with premature infants: $16 \%$ of premature infants amongst the offspring of preeclamptic women and $6 \%$ amongst those of the control series.

The duration of breast feeding has also been studied. In this analysis 115 pre-eclamptic women were followed up for six months after their confinement; 89 were entirely breast feeding, and 26 were partially breast feeding their infants when they left hospital. The number who breast fed for one, two, three, four, five and six months was determined and the percentage of women breast feeding each month calculated from these figures. The results are given in Fig. 2 with the results for a control series, which comprised 202 women who were fully breast feeding their infants and 143 partially breast feeding their infants when they left hospital. They were followed up and investigated in exactly the same way as was the group of pre-eclamptic women. No twins were included in the series. From Fig. 2 it is apparent that pre-eclamptic women who were entirely breast feeding their infants in the second week of the puerperium lactated as

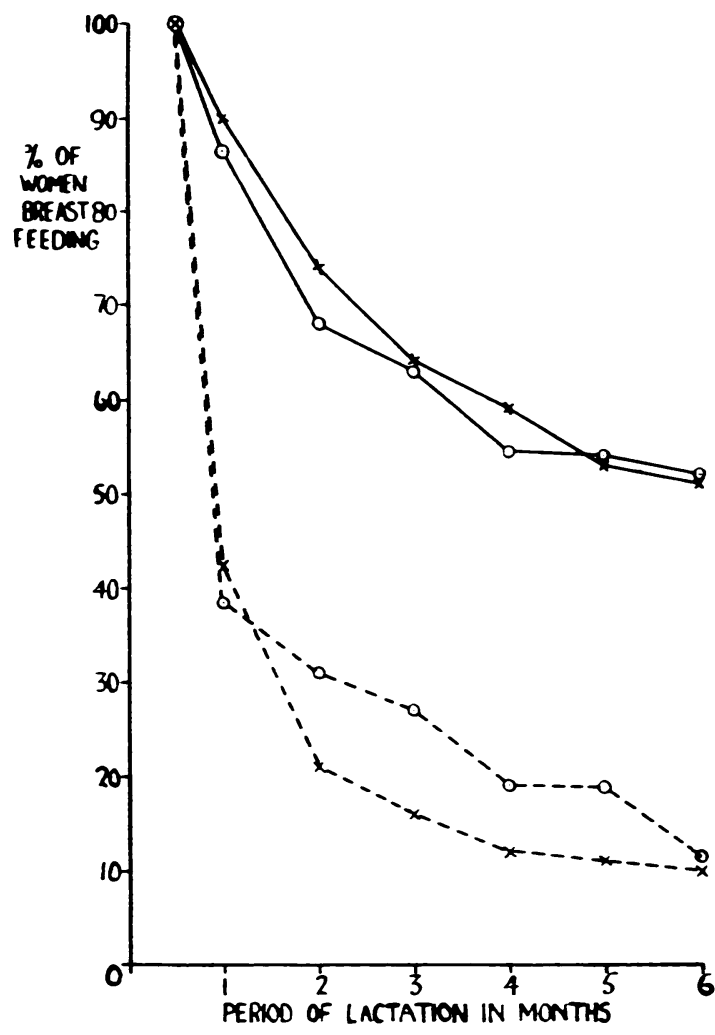

FrG. 2.

Frg. 2.-The duration of breast feeding among pre-eclamptic (0) and non-pre-eclamptic $(x)$ women. Values are given for women in both groups who had adequate (-) and inadequate $(---)$ lactation in the second week of the puerperium.

successfully as the control group of women, while the majority of both the pre-eclamptic women and the control group who left hospital giving complementary feeds very soon stopped breast feeding their infants. It is, therefore, apparent that if a pre-eclamptic woman is able to breast feed her infant adequately by the tenth day of the puerperium she is likely to be able to breast feed her infant for six months as any other woman with an adequate

TABLE 6

Incidence of Different Types of Infant Feeding in Pre-eclamptic and Non-Pre-eclamptic (CoNTrol Group) Mothers IN THE Second WeEk OF THE PUerperium

\begin{tabular}{|c|c|c|c|c|c|}
\hline \multirow[b]{2}{*}{ Group } & \multirow[b]{2}{*}{$\begin{array}{l}\text { Maturity } \\
\text { of Infant }\end{array}$} & \multirow[b]{2}{*}{$\begin{array}{l}\text { No. of } \\
\text { Cases }\end{array}$} & \multicolumn{3}{|c|}{ Percentage } \\
\hline & & & $\begin{array}{l}\text { Completely } \\
\text { Breast } \\
\text { Feeding }\end{array}$ & $\begin{array}{l}\text { Partially } \\
\text { Breast } \\
\text { Feeding }\end{array}$ & $\begin{array}{c}\text { Artificially } \\
\text { Feeding }\end{array}$ \\
\hline $\begin{array}{l}\text { Pre-eclamptic } \\
\text { Control } \\
\text { Pre-eclamptic } \\
\text { Control }\end{array}$ & $\begin{array}{l}\text { Mature } \\
\text { Mature } \\
\text { Mature and immature } \\
\text { Mature and immature }\end{array}$ & $\begin{array}{r}244 \\
1,899 \\
292 \\
3,058\end{array}$ & $\begin{array}{l}69 \cdot 7 \\
79 \cdot 5 \\
59 \cdot 6 \\
76 \cdot 6\end{array}$ & $\begin{array}{r}13 \cdot 5 \\
10 \cdot 3 \\
12 \cdot 3 \\
9 \cdot 9\end{array}$ & $\begin{array}{l}16 \cdot 8 \\
10 \cdot 2 \\
28 \cdot 1 \\
13 \cdot 4\end{array}$ \\
\hline
\end{tabular}


supply of breast milk on the tenth day. They do, however, find greater difficulty in establishing adequate lactation during the first two weeks of the puerperium than do women who have not suffered from pre-eclamptic toxaemia. The percentage of women with impaired lactation attributable to pre-eclamptic toxaemia is small, for it is a fraction of the $7.5 \%$ who leave hospital with a history of pre-eclampsia during their pregnancy.

\section{Conclusion}

A series of investigations on the incidence and duration of breast feeding were made on women who were treated both as in-patients and as out-patients in the Simpson Memorial Maternity Pavilion, Edinburgh, between January, 1947, and June, 1950.

Elderly women more frequently gave complementary or artificial feeds to their infants than younger women in the first two weeks of the puerperium; those giving complementary feeds usually stopped breast feeding within a month of parturition, while those giving entirely breast feeds lactated adequately, in $50 \%$ of cases, for six months. This applied to both young and old mothers.

Women under $5 \mathrm{ft}$. more frequently weaned their infants prematurely than taller women. This difference was apparent after the second week of lactation and only between the third and twentysixth week of lactation.

Women whose weight was above the average for their age and height in the third and fourth week of the puerperium breast fed their infants as well as those whose weight was below average. A small group whose weight was below the minimum for their age and height had considerably more difficulty in breast feeding than heavier women. This latter observation may be of practical importance, and further observations into markedly underweight women would be of interest.

A study of women's weights between the third week and the twenty-sixth week after parturition showed that $70 \%$ of mothers who breast feed their infants for six months lost from 1 to $23 \mathrm{lb}$. in weight during that time. Thirty-six per cent. of all women who breast fed for six months had returned to their pre-pregnant weight by the end of that time. Almost $30 \%$ of women breast feeding for six months gained weight, their gain being 1 to $64 \mathrm{lb}$. The rise or fall in weight, even if marked, did not appear to affect the mother's health adversely. Nor did it appear to affect the infant's weight progress.

In the first two weeks of the puerperium more pre-eclamptic women required to give their infants complementary feeds and artificial feeds than did the control group; those giving complementary feeds usually failed to breast feed within a month of parturition, while $50 \%$ of those entirely breast feeding lactated adequately for six months. This applied to both the pre-eclamptic and control group of women. The greater difficulty in breast feeding in pre-eclamptic women was attributed partly to the mother's illness and partly to the higher incidence of prematurity in such women.

Impaired lactation due to age or small stature or pre-eclamptic toxaemia accounted for a very small proportion of women who prematurely wean their infants.

\section{REFERENCES}

Antonov, A. N. (1947). J. Pediat., 30, 250.

Ashkar, P. A. (1950). J. Obstet. Gynaec. Brit. Emp., $57,78$.

Bendix, B. (1928). Mschr. Kinderheilk., 41, 422. Cited by Herlitz, 1946.

Brash, A. A. (1948). - The Effects of the Toxaemia of Pregnancy upon the Foetus and Newborn Child.' M.D. Thesis, Edinburgh.

Broman, B., Dahlberg, G. and Lichtenstein, A. (1942). Acta paediatr., Stockh., 30, 1.

Cameron, A. T. (1947). - Recent Advances in Endocrinology, 6th ed., p. 393. London.

Dean, R. F. A. (1949). Brit. med. J., 2, 1526.

Douglas, J. W. B. (1950). J. Obstet. Gynaec. Brit. Emp., 57, 335.

Dykes, R. M. (1949). Pub. Hlth, Lond., 62, 118.

Finkelstein, H. (1921). - Lehrbuch der Säuglingskrankheiten,'2nd ed. Berlin. Cited by Ylinen. 1937.

Friedländer (1917). Cited by Herlitz. 1946.

Herlitz, G. (1946). Acta pediatr., Stockh., 34, 234.

Joslin, E. P. (1940). 'Treatment of Diabetes Mellitus.' 7th ed., p. $728 . \quad$ London.

Kerpel-Fronius, E. (1947). J. Pediat., 30, 244.

König. H. (1939). Mïnch. med. Wschr., 86, 497. (1939). Nutrit. Abstr. Rev., 9, 142.

Kütting, A. (1921). Zbl. Gynäk., 45, 166.

Laurentius, J. (1911). Arch. Kinderheilk.. 56, 275

Macy, I. G., Hunscher, H. A., Donelson, E. and Nims, B. (1930). Amer. J. Dis. Child., 39, 1186.

Norval, M. A. (1947). J. Pediat., 31, 415.

Peckham, C. H. (1933). J. Amer. med. Ass., 101. 1608. (1934). Johns Hopk. Hosp. Bull., 54, 186.

Robinson, M. (1942). Archives of Disease in Childhood. $17,23$.

Royal College of Obstetrics and Gynaecologists and Population Investigation Committee. (1948). 'Maternity in Great Britain.' London.

Schlossmann. A. (1905). Arch. Kinderheilk., 43. 207.

Stander, H. J. and Pastore, J. B. (1940). Amer. J. Obstet. Ginec.. 39, 928.

Stewart, H. L. and Pratt, J. P. (1941). West J. Surg.. $49,98$.

Ström, J. (1947). Proc. 8th Northern Pediatric Conference. Helsingfors, 1946. Acta paediatr.. Uppsala, 35, Suppl. 1, p. 55.

Waller, H. (1950). Lancet, i, 53.

Wardlaw, H. S. H. and Dart, E. E. P. (1934). Med. J. Aust., 2, 377.

Werner, A. A. (1942). Endocrinology. Clinical Application and Treatment,' 2nd ed.. p. 128. Philadelphia. London.

Woodbury, R. M. (1925). Causal Factors in Infant Mortality.' U.S. Department of Labor, Children's Bureau, Publ. No. 142.

Ylinen, L. (1937). Acta paediatr., Stockh.. 21, 47. 